HETEROCYCLES, Vol. 86, No. 1, 2012, pp. -. (C) The Japan Institute of Heterocyclic Chemistry

Received, 26th June, 2012, Accepted, 3rd August, 2012, Published online,

DOI: $10.3987 / C O M-12-S(N) 60$

\title{
NOVEL EFFICIENT SYNTHESIS AND PROPERTIES OF 5,6-DIHYDROCYCLOHEPTA[b]INDOL-6-ONE, AND ITS TRANSFORMATION TO 6-AZOLYL-5-AZABENZ[b]AZULENES
}

\section{Mitsunori Oda,* Kunihiro Ito, Hiroshi Takagi, and Yurie Fujiwara}

Department of Chemistry, Faculty of Science, Shinshu University, Asahi 3-1-1, Matsumoto, Nagano, 390-8621 Japan, e-mail: mituoda@ shinshu-u.ac.jp

\begin{abstract}
The title compound, 5,6-dihydrocyclohepta[b]indol-6-one (1), was synthesized from 2-chlorotropone (7) by a two-step sequence involving Pd-catalyzed amination with 2-bromoaniline (15) and subsequent Pd-catalyzed intramolecular Heck reaction. Besides its synthetic detail, some physical properties of $\mathbf{1}$, such as acidity, basicity and spectroscopic behavior, were also reported. Compound 1 was transformed into 6-(1H-pyrazol-1-yl)- and 6-(1H-1,2,3-triazol-1-yl)-5-azabenz[b]azulenes (13 and 14) as a potential ligand.
\end{abstract}

This paper is dedicated to Professor Dr. Ei-ichi Negishi on the occasion of his 77th birthday

\section{INTRODUCTION}

The title compound, 5,6-dihydrocyclohepta[b]indol-6-one (1), ${ }^{1}$ has been known since 1972 . Boyer et al . reported the synthesis of $\mathbf{1}$ by basic hydrolysis of 6-amino-5-azabenz[ $b]$ azulene (2), which was obtained in the photochemical intramolecular insertion reaction of 2,2'-diisocyanobiphenyl (3) (Scheme 1).2 Almost at the same time, Kaneko et al. reported that $\mathbf{1}$ formed in the photochemical rearrangement of acridine 10-oxide (4), accompanied with 5 and $6 .{ }^{3}$ Later, Nozoe and Yamane et al. applied the Fischer indole synthesis to substrates containing a seven-membered ring and found two synthetic ways to $\mathbf{1}$ on a preparative scale. ${ }^{4.5}$ In one way, 9 was synthesized by the reaction of cyclohexanone and 2-hydrazinotropone (8), which can be obtained from 2-chlorotropone (7), and, then, dehydrogenation of 9 provided 1. In another way, $\mathbf{1 1}$ was synthesized by the Fischer indole synthesis with the phenylhydrazone of cycloheptane-1,2-dione (10), and $\mathbf{1}$ was obtained by dehydrogenation of $\mathbf{1 1}$ via a brominated intermediate. Interestingly, the carbon famework of 1 can be found in a marine bis(indole) alkaloid, 
Boyer et al.

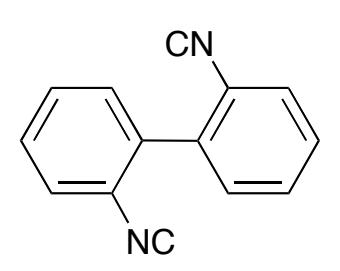

3

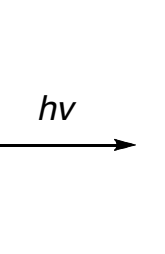

1

2

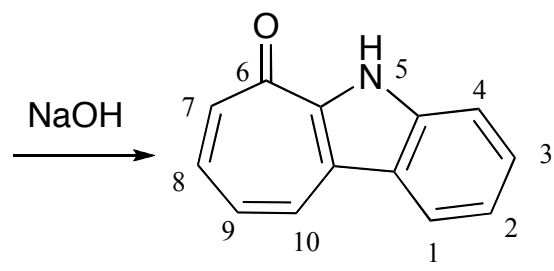

1

Kaneko et al.<smiles>O=c1ccccc2[nH]c3cc[cH+]ccc3c12</smiles>

Nozoe and Yamane et al.

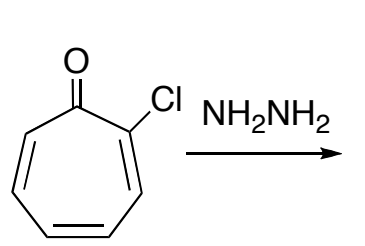

7

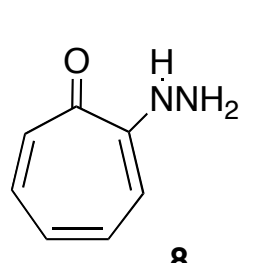

8

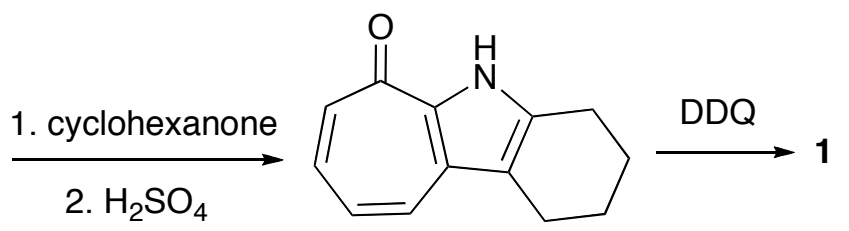

9<smiles>O=C1CCCCCC1=O</smiles>

$\underset{\text { 1. } \mathrm{PhNHNH}_{2}}{\text { 2. } \mathrm{H}_{2} \mathrm{SO}_{4}}$<smiles>O=C1CCCCc2c1[nH]c1ccccc21</smiles>

Scheme 1. Previously reported synthetic methods for $\mathbf{1}$

caulersin (12), whose synthetic benzo analogs show potent antitumor activity. ${ }^{7}$ Meanwhile, 1-azaazulenyl compounds have recently been paid attention to as a ligand, ${ }^{8}$ and, hence, we have been interested in $\mathbf{1}$ as a bidentate ligand structurally related to 1-azaazulenens and application of its metal complex for functionalized materials, particularly as an electroluminescent compound. ${ }^{9}$ Therefore, we have been curious to know basic properties of $\mathbf{1}$ for investigation of its metal complexation and also required a more convenient synthesis of $\mathbf{1}$. In this paper, we describe an alternative efficient synthesis of $\mathbf{1}$, and its properties such as<smiles>COC(=O)c1cc2c([nH]c3ccccc32)c(=O)c2c1[nH]c1ccccc12</smiles>

12

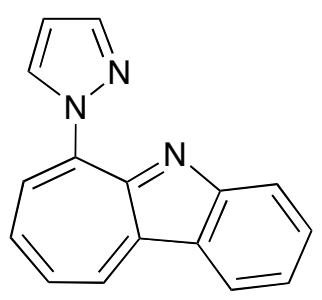

13

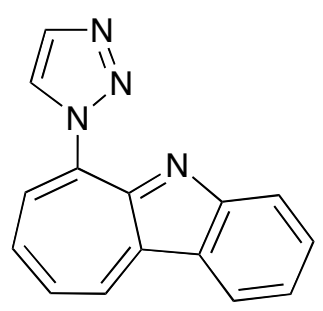

14

acidity, basicity and Chart 1. Structure of caulersin (12).

Chart 2. Structures of 13 and 14. 
interaction with metal ions. Also, transformation of $\mathbf{1}$ into azole-substituted 5-azabenz[b]azulenes, $\mathbf{1 3}$ and $\mathbf{1 4}$, as a potential ligand is described.

\section{RESULTS AND DISCUSSION}

\section{Development of a new synthetic method for 1}

In this study, a short-step strategy for synthesizing 1 from 2-substituted tropones and 2-bromoaniline (15) by Pd-catalyzed amination and subsequent intramolecular Heck reaction was investigated. Although it has been known that 2-anilinotropones could be obtained by nucleophilic substitution reaction of various tropone derivatives having a leaving group at the 2-position with some unhindered anilines, ${ }^{10}$ Brookhart et al. reported that reaction of sterically hindered aniline with 2-tosyloxytropone (16) gave the ring-contraction compound as a major product. ${ }^{11}$ They deviced Pd-catalyzed amination using 2-triflatotropone (17) as an alternative method for synthesizing 2-anilinotropones. Since $\mathbf{1 5}$ does not react with various 2-substituted tropones under conventional conditions, the Pd-catalyzed amination under reaction conditions reported by Brookhart et al. was applied to preparation of 2-(2-bromoanilino)tropone (20) in our study. The results are listed in Table 1. 2-Iodotropone (18) and 2-bromotropone (19) were used in addition to $\mathbf{7 , 1 6}$, and $\mathbf{1 7 .}$

Table 1. Palladium-catalyzed amination of 2-substituted tropones with $\mathbf{1 5}$

\begin{tabular}{|c|c|c|c|c|}
\hline \multicolumn{5}{|c|}{$\begin{array}{l}\mathrm{Y}=\text { OTs (16), OTf (17), } \\
\mathrm{I}(\mathbf{1 8}), \mathrm{Br}(\mathbf{1 9}), \mathrm{Cl}(\mathbf{7})\end{array}$} \\
\hline entry & $\mathrm{Y}$ & Pd / BINAP ${ }^{a}$ & solvent / temp / time & yield of $20(\%)^{b}$ \\
\hline 1 & OTs & $3 \mathrm{~mol} \% \mathrm{Pd}_{2}(\mathrm{dba})_{3} / 6 \mathrm{~mol} \%$ BINAP & toluene $/ 80^{\circ} \mathrm{C} / 6 \mathrm{~h}$ & $15^{\mathrm{c}}$ \\
\hline 2 & OTs & $3 \mathrm{~mol} \% \mathrm{Pd}_{2}(\mathrm{dba})_{3} / 6 \mathrm{~mol} \%$ BINAP & toluene / reflux / $12 \mathrm{~h}$ & 25 \\
\hline 3 & OTf & $3 \mathrm{~mol} \% \mathrm{Pd}_{2}(\mathrm{dba})_{3} / 6 \mathrm{~mol} \%$ BINAP & toluene $/ 80^{\circ} \mathrm{C} / 6 \mathrm{~h}$ & 52 \\
\hline 4 & I & 3 mol $\% \operatorname{Pd}_{2}(\mathrm{dba})_{3} / 6$ mol\% BINAP & toluene / reflux / $20 \mathrm{~h}$ & 14 \\
\hline 5 & $\mathrm{Br}$ & 3 mol $\% \mathrm{Pd}_{2}(\mathrm{dba})_{3} / 6$ mol$\%$ BINAP & toluene / reflux / $15 \mathrm{~h}$ & 60 \\
\hline 6 & $\mathrm{Cl}$ & $3 \mathrm{~mol} \% \mathrm{Pd}_{2}(\mathrm{dba})_{3} / 6 \mathrm{~mol} \%$ BINAP & toluene / reflux / $12 \mathrm{~h}$ & 80 \\
\hline 7 & $\mathrm{Cl}$ & $1 \mathrm{~mol} \% \mathrm{Pd}_{2}(\mathrm{dba})_{3} / 2$ mol$\%$ BINAP & toluene / reflux / $16 \mathrm{~h}$ & 52 \\
\hline 8 & $\mathrm{Cl}$ & $5 \mathrm{~mol} \% \mathrm{Pd}_{2}(\mathrm{dba})_{3} / 10 \mathrm{~mol} \%$ BINAP & toluene / reflux / $4 \mathrm{~h}$ & 71 \\
\hline 9 & $\mathrm{Cl}$ & $3 \mathrm{~mol} \% \mathrm{Pd}_{2}(\mathrm{dba})_{3} / 6 \mathrm{~mol} \%$ BINAP & xylene / reflux / $5 \mathrm{~h}$ & 60 \\
\hline
\end{tabular}

a 1.2 eq. of 15 and 1.4 eq. of $\mathrm{Cs}_{2} \mathrm{CO}_{3}$ were used in all reactions, ${ }^{\mathrm{b}}$ Isolated yield after chromatography

${ }^{\mathrm{c}}$ Recovery (36\%) of $\mathbf{1 6}$ was observed. 
Among the 2-substituted tropones used, 7 was surprisingly found to be the most reactive under the conditions and 20 was obatained in a satisfactory yield (Table 1, entry 6). The order of reactivity of arylhalides in Pd-catalyzed aminations is usually iodide $>$ bromide $>$ chloride. Therefore, polarizability of $\mathrm{C}-\mathrm{X}$ bond has been thought to be important in an oxidative insertion of $\operatorname{Pd}(0)$. However, the order of reactivity of 2-halorotropones in our amination is roughly chloride $>$ bromide $>$ iodide (Table 1, entries 4 , 5 , and 6), as seen in ionic nucleophilic substitution reactions of arylhalides. ${ }^{12}$ This reactivity suggests that charge density at the C-2 atom seems to play an important role in this amination reaction.

Table 2. Palladium-catalyzed intramolecular Heck reaction of $\mathbf{2 0}$
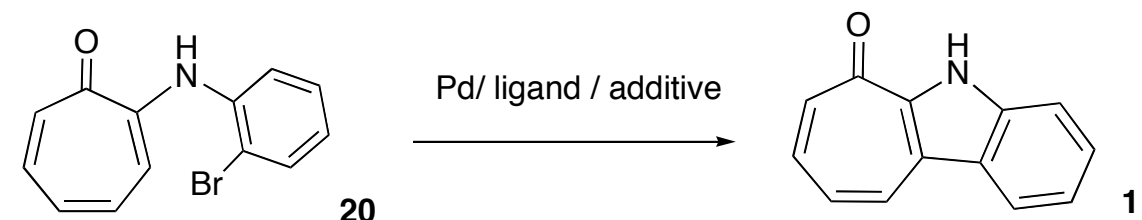

\begin{tabular}{|c|c|c|c|}
\hline entry & $\mathrm{Pd} /$ ligand / additive & solvent / temp / time & yield of $1(\%)^{a}$ \\
\hline 1 & $3 \mathrm{~mol} \% \mathrm{Pd}_{2}(\mathrm{dba})_{3} / 6 \mathrm{~mol} \% \mathrm{P}(t-\mathrm{Bu})_{3} / 1.0$ eq $\mathrm{DABCO}$ & $\mathrm{CH}_{3} \mathrm{CN} /$ reflux / $18 \mathrm{~h}$ & trace \\
\hline 2 & $5 \mathrm{~mol} \% \mathrm{Pd}(\mathrm{OAc})_{2} / 20 \mathrm{~mol} \% \mathrm{P}(o \text {-tol })_{3} / 1.3 \mathrm{eq} \mathrm{Et}_{3} \mathrm{~N}$ & dioxane / reflux / $27 \mathrm{~h}$ & 0 \\
\hline 3 & $10 \mathrm{~mol} \% \mathrm{Pd}(\mathrm{OAc})_{2} / 40 \mathrm{~mol} \% \mathrm{P}(o-\mathrm{tol})_{3} / 1.3 \mathrm{eq} \mathrm{Et}_{3} \mathrm{~N}$ & $\mathrm{DMF} / \mathrm{reflux} / 18 \mathrm{~h}$ & 6 \\
\hline 4 & $2 \mathrm{~mol} \% \mathrm{Pd}\left(\mathrm{PPh}_{3}\right)_{4} / 2.0 \mathrm{eq} \mathrm{NaHCO}_{3}$ & $\mathrm{HMPA} / 80^{\circ} \mathrm{C} / 23 \mathrm{~h}$ & $29^{b}$ \\
\hline 5 & $5 \mathrm{~mol} \% \mathrm{Pd}(\mathrm{OAc})_{2} / 1.0 \mathrm{eq}(\mathrm{Bu})_{4} \mathrm{~N}^{+} \mathrm{Br}^{-}$ & $\mathrm{DMF} / \mathrm{reflux} / 9 \mathrm{~h}$ & 22 \\
\hline 6 & $10 \mathrm{~mol} \% \mathrm{Pd}(\mathrm{OAc})_{2} / 10 \mathrm{~mol} \% \mathrm{P}(o \text {-tol })_{3} / 1.3 \mathrm{eq} \mathrm{K}_{2} \mathrm{CO}_{3}$ & $\mathrm{DMF} /$ reflux / $23 \mathrm{~h}$ & 57 \\
\hline 7 & $10 \mathrm{~mol} \% \mathrm{Pd}(\mathrm{OAc})_{2} / 40 \mathrm{~mol} \% \mathrm{P}(o \text {-tol })_{3} / 1.3 \mathrm{eq} \mathrm{K}_{2} \mathrm{CO}_{3}$ & $\mathrm{DMF} / \mathrm{reflux} / 23 \mathrm{~h}$ & 54 \\
\hline 8 & $10 \mathrm{~mol} \% \mathrm{Pd}(\mathrm{OAc})_{2} / 20 \mathrm{~mol} \% \mathrm{P}(o-\text { tol })_{3} / 1.0 \mathrm{eq} \mathrm{AcOH} / 2.0 \mathrm{eq} \mathrm{AcONa}$ & $\mathrm{DMF} /$ reflux / $8 \mathrm{~h}$ & 79 \\
\hline 9 & $10 \mathrm{~mol} \% \mathrm{Pd}(\mathrm{OAc})_{2} / 20 \mathrm{~mol} \% \mathrm{P}(o \text {-tol })_{3} / 3.0 \mathrm{eq} \mathrm{AcOH} / 0.5 \mathrm{eq} \mathrm{AcONa}$ & $\mathrm{DMF} /$ reflux / $8 \mathrm{~h}$ & $40^{\mathrm{c}}$ \\
\hline 10 & $10 \mathrm{~mol} \% \mathrm{Pd}(\mathrm{OAc})_{2} / 20 \mathrm{~mol} \% \mathrm{XPhos} / 1.0 \mathrm{eq} \mathrm{AcOH} / 2.0 \mathrm{eq} \mathrm{AcONa}$ & $\mathrm{DMF} /$ reflux / $27 \mathrm{~h}$ & 90 \\
\hline 11 & $10 \mathrm{~mol} \% \mathrm{Pd}(\mathrm{OAc})_{2} / 20 \mathrm{~mol} \% \mathrm{XPhos} / 2.0 \mathrm{eq} \mathrm{AcOH} / 2.0 \mathrm{eq} \mathrm{AcONa}$ & $\mathrm{DMF} /$ reflux / $27 \mathrm{~h}$ & $73^{c}$ \\
\hline
\end{tabular}

${ }^{\mathrm{a}}$ Isolated yield after chromatography, ${ }^{\mathrm{b}}$ accompanied with $5 \%$ yield of cyclohepta $[b][1,4]$ benzoxazine, ${ }^{\mathrm{c}}$ accompanied with a reduction product, 2-anilinotropone.

Next, with a substantial amount of $\mathbf{2 0}$ in a hand, its intramolecular Heck reaction was examined to complete synthesis of the title compound 1. We applied Heck reaction conditions with various palladium catalysts and phosphine ligands. The results are summarized in Table 2. Under the conditions of entries $1-5$, the yields of 1 were poor or none. Although 1 was obtained under the conditions with $\mathrm{Pd}(\mathrm{OAc})_{2} / \mathrm{P}(o \text {-tol })_{3} / \mathrm{K}_{2} \mathrm{CO}_{3} / \mathrm{DMF}$ (Table 2, entries 6 and 7), the yields of 1 were still moderate. Addition of weak base and its conjugated acid was found effective to improve the yield (Table 2, entry 8). However, under acidic conditions with a larger amount of acetic acid the yield of $\mathbf{1}$ was reduced, accompanied with 
formation of a reduction product (Table 2, entries 9 and 11). The satisfactory yield of $90 \%$ was achieved under the conditions with sterically hindered ligand, $\operatorname{XPhos}^{13}$ (Table 2, entry 10). The title compound 1 is now available in two steps from $\mathbf{7}$ and $\mathbf{1 5}$ in good yields (Scheme 2). Although palladium reagents are used in these two procedurers, transformation to $\mathbf{1}$ from $\mathbf{7}$ in one pot was not achieved yet in spite of extensive attempts.

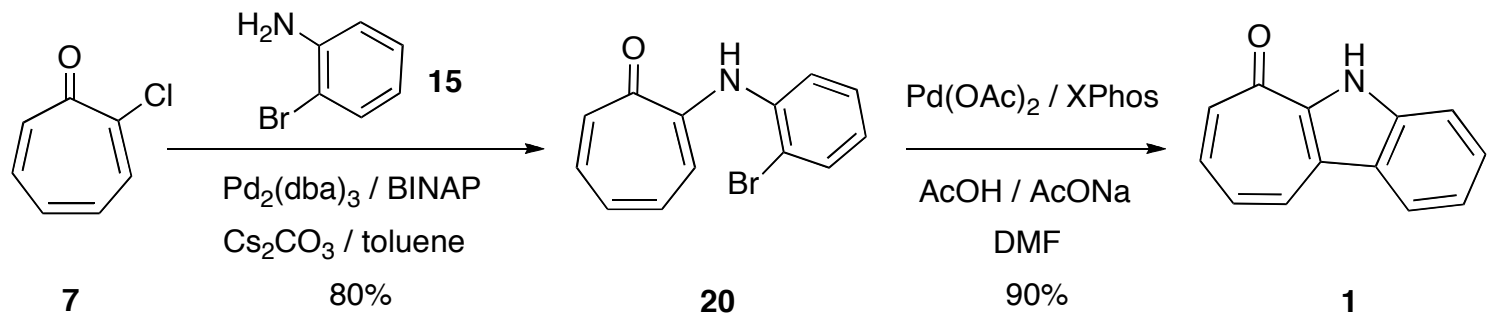

Scheme 2. Summary of the sysnthesis of $\mathbf{1}$

\section{Some physical properties of 1}

Compound 1 was isolated as yellow prisms. Although some spectral data were previously reported, those were renewed by data measured with high-resolution machines. All ${ }^{1} \mathrm{H}$ and ${ }^{13} \mathrm{C}$ NMR signals are assigned with the aid of HMQC and HMBC spectra (Figure 1). Behavior of $\mathbf{1}$ in both acidic $\left(\mathrm{CF}_{3} \mathrm{CO}_{2} \mathrm{D}\right)$ and basic $\left(\mathrm{NaOD} / \mathrm{D}_{2} \mathrm{O} / \mathrm{DMSO}-d_{6}\right)$ media was also investigated by ${ }^{1} \mathrm{H}$ NMR analysis. The average chemical shift (8.29 ppm) of hydrogens on the sp2 carbon atoms in $\mathrm{CF}_{3} \mathrm{CO}_{2} \mathrm{D}$ shows a down-filed shift compared with
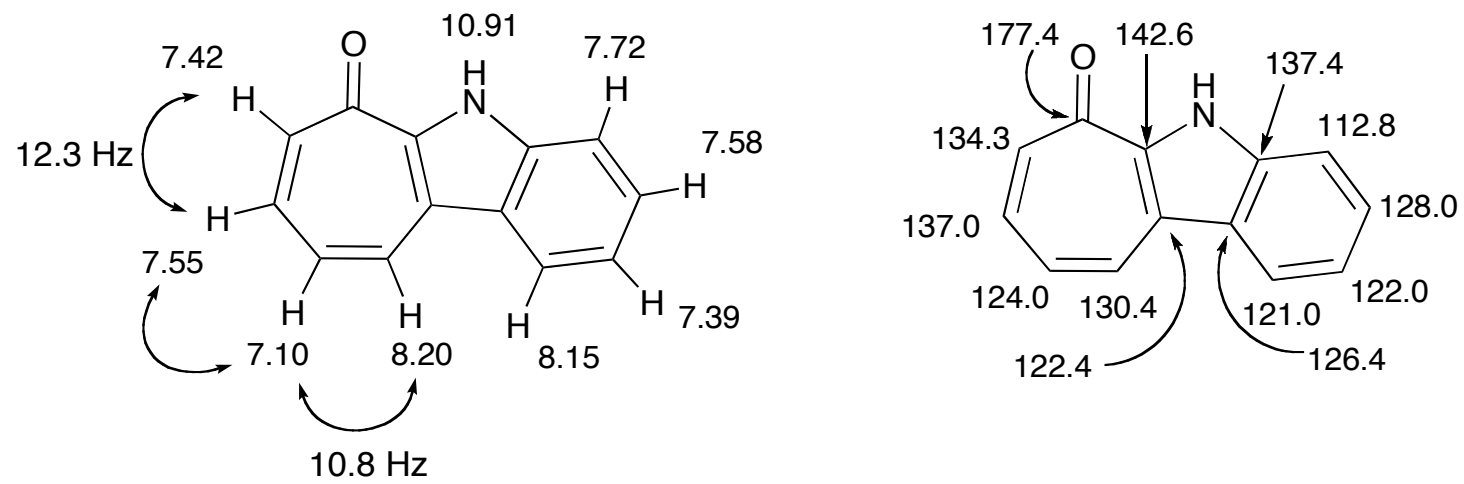

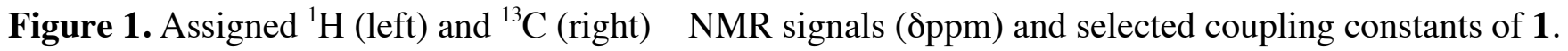

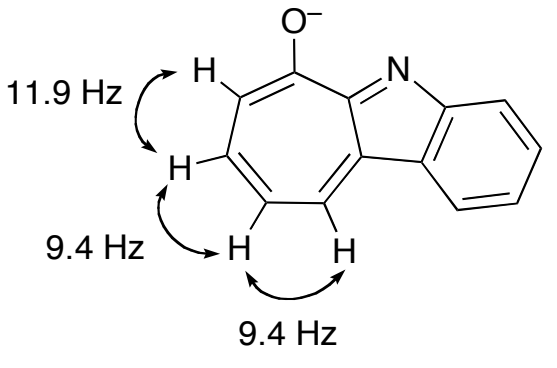

$1^{-}$
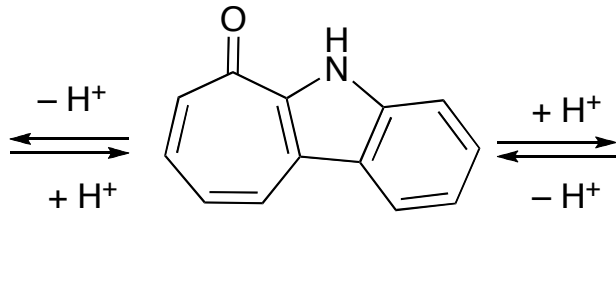

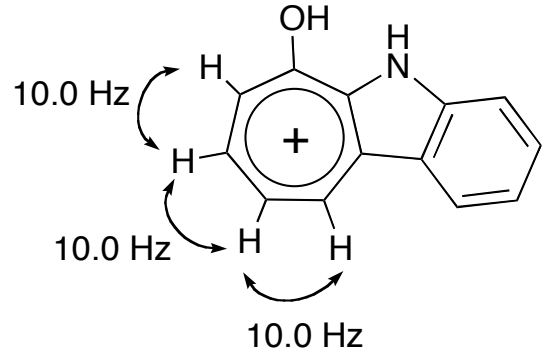

$1^{+}$

Scheme 3. Selected coupling constants of protonated and deprotonated spieces of $\mathbf{1}$. 
that $(7.61 \mathrm{ppm})$ in $\mathrm{CDCl}_{3}$, supporting generation of the protonated species $\mathbf{1}^{+}$. It is worth noting that ${ }^{3} \boldsymbol{J}_{\mathrm{H}-\mathrm{H}}$ coupling constants between hydrogens on the seven-membered ring are same, evidencing formation of the delocalized tropylium ion structure in $\mathbf{1}^{+}$(Scheme 3 ). On the other hand, the average chemical shift in $\mathrm{NaOD} / \mathrm{D}_{2} \mathrm{O} / \mathrm{DMSO}-d_{6}(7.64 \mathrm{ppm})$ shows a very small up-field shift. However, more convergent ${ }^{3} J_{\mathrm{H}-\mathrm{H}}$ coupling constants compared with those observed in $\mathrm{CDCl}_{3}$ suggest generation of deprotonated species $\mathbf{1}^{-}$. Although electron density of the azaazulene ring increases in $\mathbf{1}^{-}$, a deshielding effect of the ring perimeter may compensate the shielding effect of negative charge in $\mathbf{1}^{-}$, resulting in the slight up-field shift.

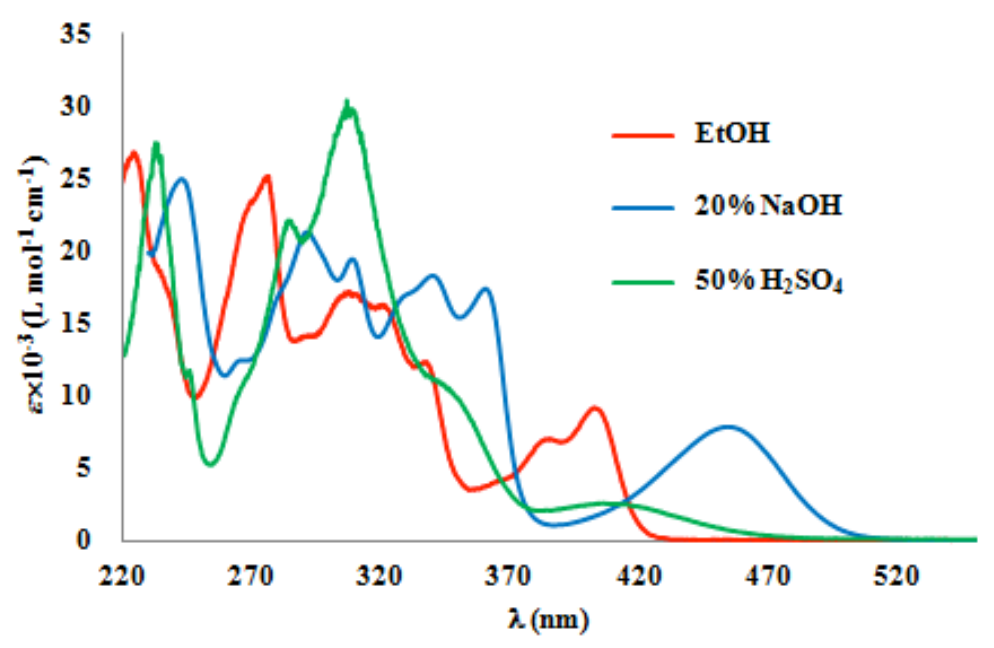

Figure 2. Absorption spectra of $\mathbf{1}$ in neutral, acidic, and basic media.

Changes of UV-vis spectra in acidic and basic media (Figure 2) also evidence the formation of ionic species, $\mathbf{1}^{+}$and $\mathbf{1}^{-}$. While the spectrum of $\mathbf{1}$ in EtOH displays mainly four bands at 224, 276, 307 and $403 \mathrm{~nm}$, the spectrum in a $50 \%$ sulfuric acid solution shows a slight red-shift of the long-wave maximum (407 nm) with a hypochromic effect and also distinct hyperchromic effect of the maximum around $310 \mathrm{~nm}$. The spectrum in a $20 \% \mathrm{NaOH}$ solution shows a clear red-shift of all bands. Particularly, the long-wave maximum shifts by $52 \mathrm{~nm}$ compared with that in EtOH. Based on these spectral changes, values of $\mathrm{p} K_{\mathrm{a}}$ and $\mathrm{p} K_{\mathrm{b}}$ for 1 were determined by a titration method. Table 3 shows the values of $\mathbf{1}$ and related compounds, indole, ${ }^{14}$ pyrrole, ${ }^{14}$-aminotropone, ${ }^{15}$ tropone ${ }^{16}$ and
Table 3. Acidity and basicity of $\mathbf{1}$ and related compounds

\begin{tabular}{ccc}
\hline compound & $\mathrm{p} K_{\mathrm{a}}$ & $\mathrm{p} K_{\mathrm{b}}$ \\
\hline $\mathbf{1}$ & 13.6 & 12.9 \\
indole $^{\mathrm{a})}$ & 20.95 & - \\
pyrrole $^{\mathrm{a})}$ & 23.05 & - \\
2-aminotropone $^{\mathrm{b})}$ & - & 11.79 \\
tropone $^{\mathrm{c})}$ & - & 15.02 \\
$\mathbf{2 1}^{\mathrm{d})}$ & - & 7.3 \\
\hline
\end{tabular}

a) Measured in DMSO. Taken from ref $14 .{ }^{\text {b) }}$ Measured in hydrochloric acid solutions. Taken from ref $15 .^{c)}$ Measured in sulfuric acid solutions. Taken from ref $16{ }^{\mathrm{d})}$ Measured in $50 \%$ aqueous $\mathrm{MeOH}$. Taken from ref 2. See below for the structure of $\mathbf{2 1}$.

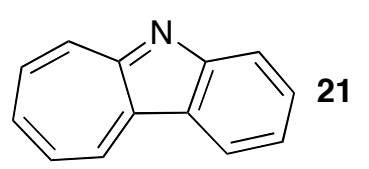


6-azabenz[b]azulene (21). ${ }^{2}$ The relatively stronger acidity of $\mathbf{1}$ compared with those of indole and pyrrole can be attributed to the annelation of an electron-withdrawing tropone to the indole skeleton. The basicity of $\mathbf{1}$ is between those of tropone and 2-aminotorpone and far lower than that of 21. These results are consistent to the previously suggested conclusion ${ }^{4}$ that $\mathbf{1}$<smiles>O=c1ccccc2c1[nH]c1ccccc12</smiles>
1

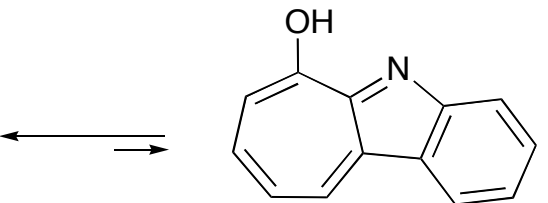

22 exist as a tropone-containing structure,

Scheme 4. Tautomerism of 1. depicted as 1, not as its tautomeric azaazulene structure of 22 (Scheme 4).

In order to investigate interaction between $\mathbf{1}$ and metal ions, absorption spectra of $\mathbf{1}$ in the presence of a large excess (500 eq.) of several metal ions as the perchlorate were measured. Clear spectral change was not observed in the presence of monovalant ions, such as $\mathrm{Li}^{+}, \mathrm{Na}^{+}$and $\mathrm{Ag}^{+}$, and divalent $\mathrm{Ca}^{2+}$ and $\mathrm{Mg}^{2+}$. In the presence of divalent $\mathrm{Zn}^{2+}$, the long-wave maximum was observed at $439 \mathrm{~nm}$, showing a clear red-shift (Figure 3). Emission upon excitation at $439 \mathrm{~nm}$ in the presence of $\mathrm{Zn}^{2+}$ was observed at $497 \mathrm{~nm}$. It is worth noting that an emission quantum yield $\left(\Phi=1.2 \times 10^{-2}\right)$ in the presence of $\mathrm{Zn}^{2+}$ is 23 times greater than that $\left(\Phi=5.3 \times 10^{-4}\right)$ without metal ion. ${ }^{17}$

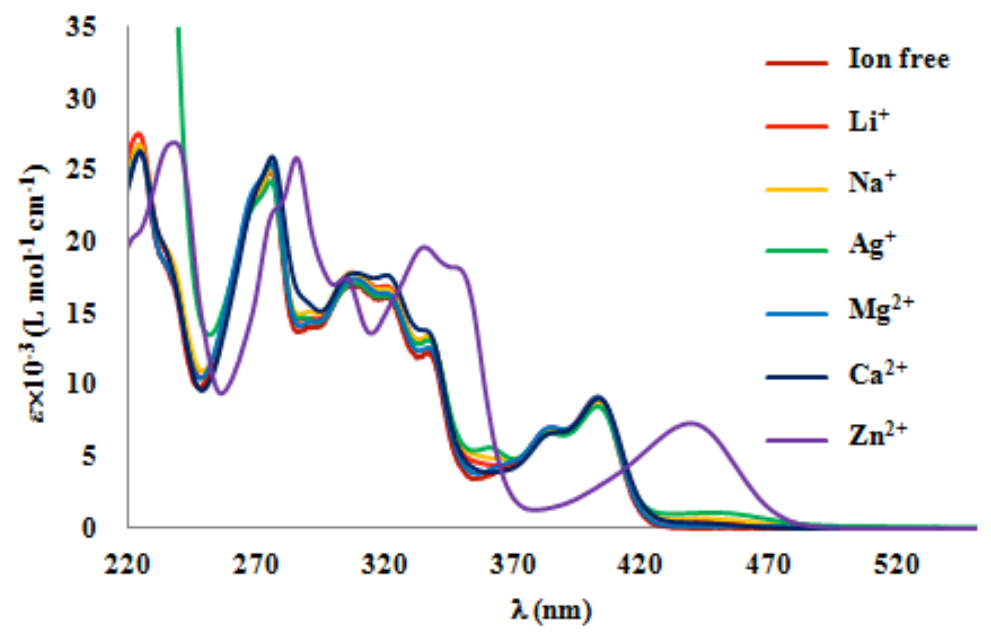

Figure 3. Absorption spectra of $\mathbf{1}$ in the presence of various metal ions.

\section{Synthesis and properties of 6-azolyl-5-azabenz $[b]$ azulenes}

Yamane et al. reported the transformation of $\mathbf{1}$ into various amine-substituted 5-azabenz[b]azulenes (24) via 6-chloro-5-azabenz $[b]$ azulene

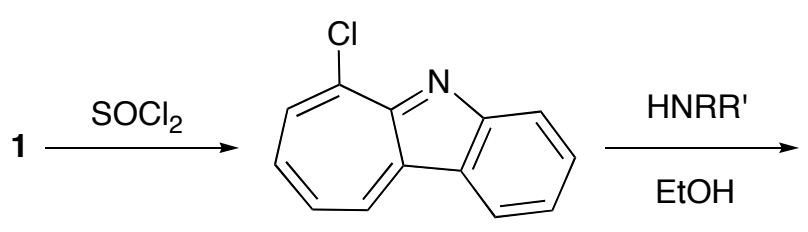

23<smiles>[R]N([R])c1ccccc2c3ccccc3nc1-2</smiles>

24

(23). ${ }^{4}$ Nucleophilic substitution

Scheme 5. Synthesis of 6-amino-5-azabenz[b]azulenes 24 by Yamane et al 
reactions of $\mathbf{2 3}$ with amines and hydrazines provide various 6-substituted derivatives in good yields by simply heating in EtOH (Scheme 5). However, less nucleophilic azoles react with 23 neither in refluxing

Table 4. Palladium-catalyzed amination of $\mathbf{2 3}$ with pyrazole and triazole

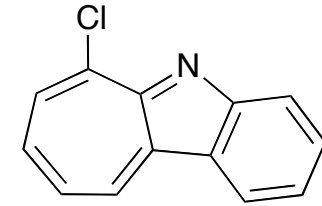

23

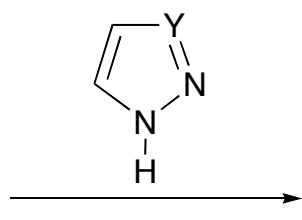

$\mathrm{Pd}_{2}(\mathrm{dba})_{3} /$ ligand

$\mathrm{Cs}_{2} \mathrm{CO}_{3}$

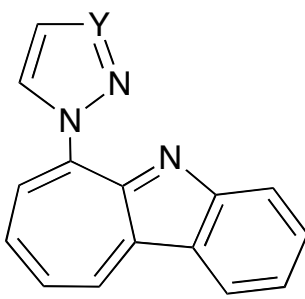

$13(\mathrm{Y}=\mathrm{CH}), 14(\mathrm{Y}=\mathrm{N})$

\begin{tabular}{clllc}
\hline entry & azole $^{\mathrm{a}}$ & $\mathrm{Pd}_{2}(\mathrm{dba})_{3} /$ ligand & solvent $/$ temp $/$ time & yield [\% $]^{\mathrm{c}}$ (product) \\
\hline 1 & pyrazole & $2.5 \mathrm{~mol} \% \mathrm{Pd}_{2}(\mathrm{dba})_{3} / 5 \mathrm{~mol} \% \mathrm{XPhos}$ & dioxane $/ \mathrm{reflux} / 6 \mathrm{~h}$ & $9(\mathbf{1 3})$ \\
2 & pyrazole & $3 \mathrm{~mol} \% \mathrm{Pd}_{2}(\mathrm{dba})_{3} / 6 \mathrm{~mol} \% \mathrm{BINAP}$ & toluene $/ \mathrm{reflux} / 9 \mathrm{~h}$ & $77(\mathbf{1 3})$ \\
3 & triazole & $6 \mathrm{~mol} \% \mathrm{Pd}_{2}(\mathrm{dba})_{3} / 12 \mathrm{~mol} \% \mathrm{BINAP}$ & toluene $/ 80^{\circ} \mathrm{C} / 14 \mathrm{~h}$ & $69(\mathbf{1 4})$ \\
4 & triazole & $10 \mathrm{~mol} \% \mathrm{Pd}_{2}(\mathrm{dba})_{3} / 20 \mathrm{~mol} \% \mathrm{BINAP}$ & toluene $/ 90^{\circ} \mathrm{C} / 20 \mathrm{~h}$ & $72(\mathbf{1 4})$ \\
\hline
\end{tabular}

a 2.0 eq. of azole was used in all reactions, ${ }^{b} 2.0$ eq. of $\mathrm{Cs}_{2} \mathrm{CO}_{3}$ were used in all reactions,

${ }^{\mathrm{c}}$ Isolated yield after chromatography.

EtOH nor under base-assisted conditions. Hence, Pd-catalyzed amination was examined. The results are shown in Table 4. The desired products $\mathbf{1 3}$ and $\mathbf{1 4}$ were obtained in good yields under the conditions $\mathrm{Pd}_{2}(\mathrm{dba})_{3} / \mathrm{BINAP} / \mathrm{Cs}_{2} \mathrm{CO}_{3}$ in refluxing toluene (entries 2-4). In the reaction with 1,2,3-triazole, a small amount of the 2-triazolyl isomer 24 was observed as another product by ${ }^{1} \mathrm{H}$ NMR analysis of the crude reaction mixture. However, 24 was not isolated

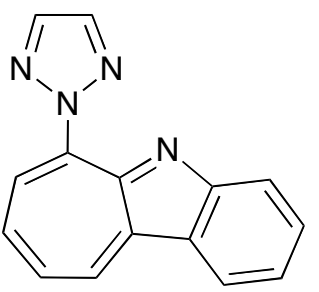

24 because of its facile hydrolysis to $\mathbf{1}$ during chromatographic purification, as Chart 3. Structure of 24 . seen in hydrolysis of $\mathbf{2}$. Compound $\mathbf{1 4}$ is more sensitive to acid and base than $\mathbf{1 3}$. Compounds $\mathbf{1 3}$ and $\mathbf{1 4}$ were isolated as violet crystals, having weak visible absorptions at 510 and $496 \mathrm{~nm}$ in EtOH, respectively (Figure 4). While no emission was observed upon excitation at those long-wave maxima, emissions at $435 \mathrm{~nm}$ were observed upon excitation at 383 for $\mathbf{1 3}$ and $385 \mathrm{~nm}$ for $\mathbf{1 4} .^{18}$ This emission behavior is resemble to that seen in azulenes. A $\mathrm{p} K_{\mathrm{b}}$ value of $\mathbf{1 3}$ was determined to be 8.4 by a UV-vis titration method, though basicity of $\mathbf{1 4}$ could not be determined because of its instability in acid and basic aqueous solutions, The value shows that $\mathbf{1 3}$ is less basic by $1.1 \mathrm{p} K_{\mathrm{b}}$ unit than the parent 6 -azabenz[b]azulene (21), indicating that the pyrazole moiety shows electron-withdrawing functionality. Absorption spectra of $\mathbf{1 3}$ and 14 in the presence of a large excess (500 eq.) of metal ions are also examined. The results are shown in Figures. 5 and 6. A blue-shifts of the long-wave absorption maxima with a hyperchromic effect for 


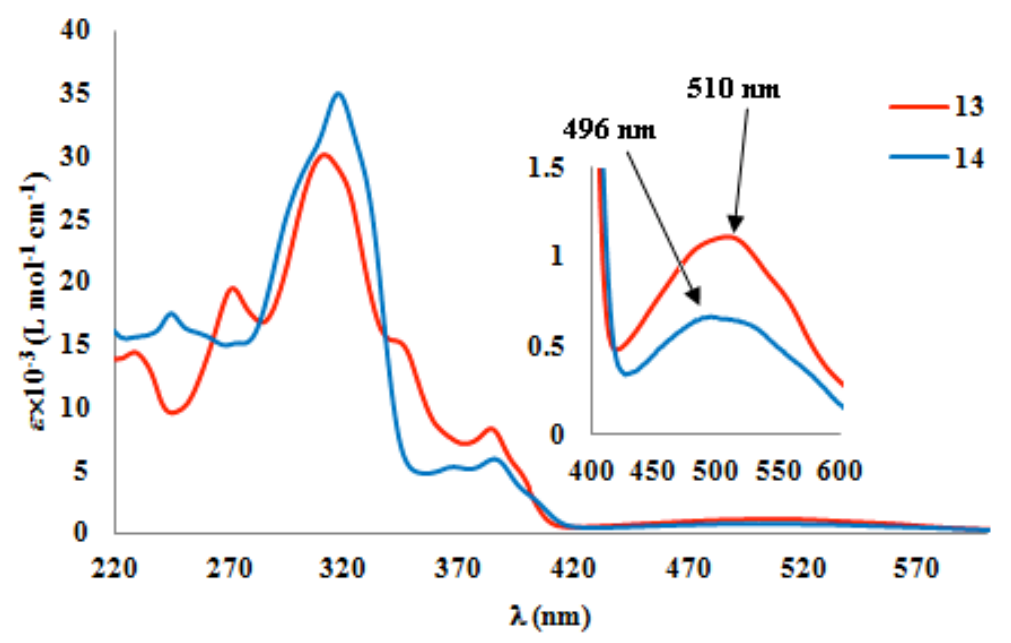

Figure 4. Absorption spectra of 13 and 14 in EtOH.

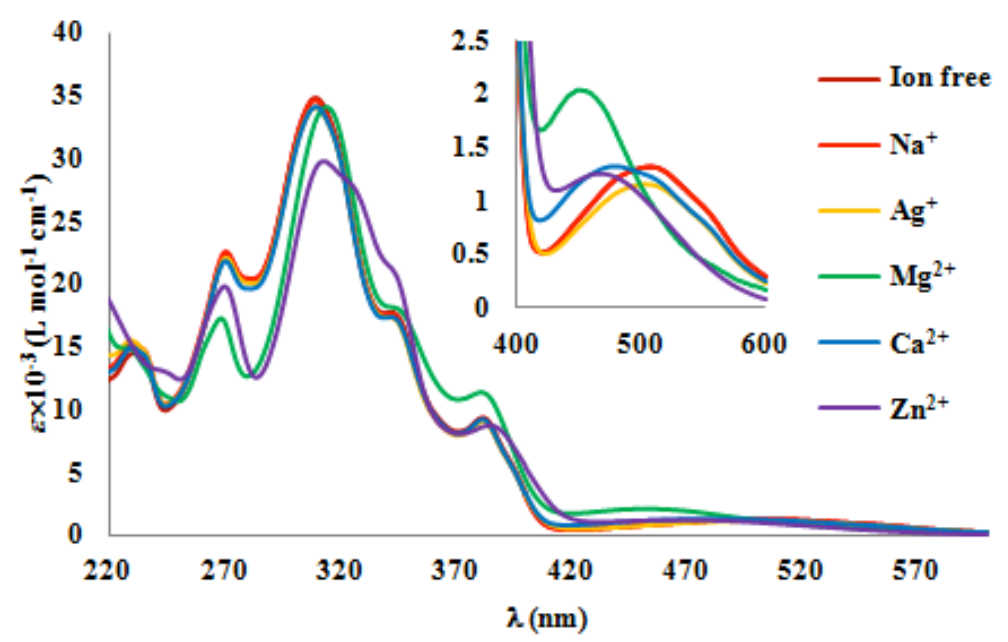

Figure 5. Absorption spectra of $\mathbf{1 3}$ in the presence of various metal ions.

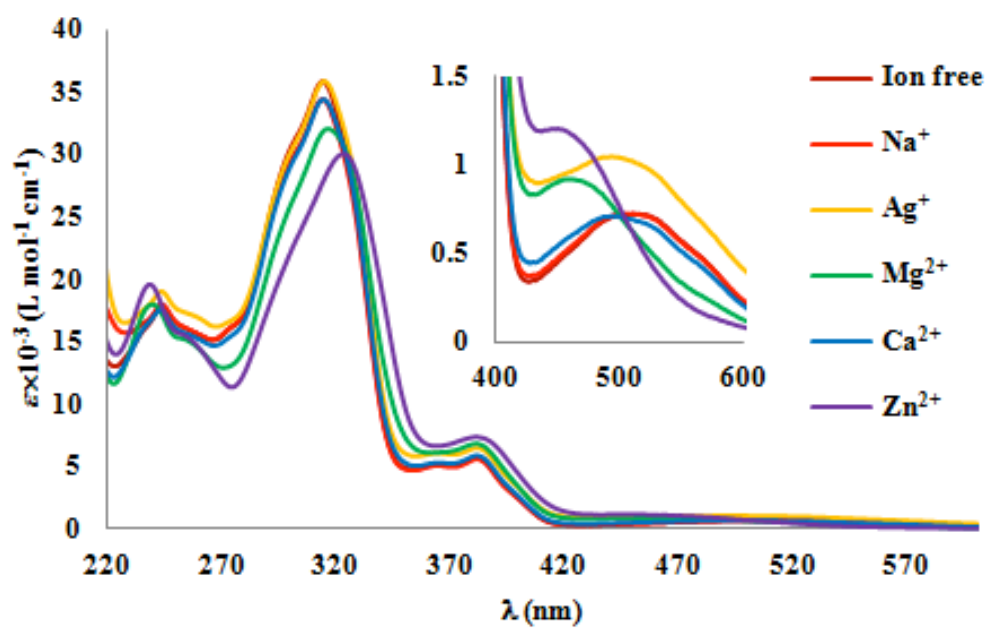

Figure 6.Absorption spectra of $\mathbf{1 4}$ in the presence of various metal ions.

$\mathrm{Mg}^{2+}$ and $\mathrm{Zn}^{2+}$ was observed for 13 and $\mathbf{1 4}$, suggesting that coordination of metal ions with their nitrogen on the 6 position occurs, though it is not clear whether azole nitrogens participate in the coordination or 
not so far. Interestingly, 13 interacts much strongly with $\mathrm{Mg}^{2+}$, while $\mathbf{1 4}$ dose with $\mathrm{Zn}^{2+}$. However, clear change of their emission spectra in the presence of metal ions was not observed.

\section{CONCLUSION}

It has been demonstrated that the title compound $\mathbf{1}$ can be efficiently synthesized from 2-chrorotropone (7) by Pd-catalyzed amination with 2-bromoamniline (15) and subsequent by Pd-catalyzed intramolecular Heck reaction. Various 2-substituted tropones were subjected to the amination and it was revealed that, among the tropones used, 2-chlorotropones (7) reacts most effectively. In the intramolecular Heck reaction, it was found that addition of weak acid and its conjugated base and use of a sterically hindered ligand was valid to improve the yield. Basicity and acidity of $\mathbf{1}$ were disclosed and its interaction with metal ions in solution was studied. The Pd-catalyzed amination of $\mathbf{2 3}$, derived from $\mathbf{1}$, with azoles gave the azolyl products $\mathbf{1 3}$ and $\mathbf{1 4}$. Some spectroscopic properties of these compounds were also clarified.

\section{EXPERIMENTAL}

Melting points were measured on a Yanaco MP-3. IR spectra were recorded on a JEOL Diamond-20 spectrometer. UV-vis spectra were measured on a Shimadzu UV-2550 spectrometer. Emission spectra were recorded on a Shimadzu RF-5300PC spectrometer. ${ }^{1} \mathrm{H}$ and ${ }^{13} \mathrm{C}-\mathrm{NMR}$ spectra were recorded with tetramethylsilane as internal standard on a JEOL $\lambda 400$ NMR instruments. Mass spectra were measured on a JMS-700 mass spectrometer. Column chromatography was done with Silica gel 60N from Kanto Chem., Inc. X-Phos, $\mathrm{Pd}_{2}(\mathrm{dba})_{3}, \mathrm{Pd}\left(\mathrm{PPh}_{3}\right)_{4}$, and $\mathrm{Cs}_{2} \mathrm{CO}_{3}$ were purchased from Sigma-Aldrich Japan, Inc. BINAP, tri-o-tolylphosphine and 2-bromoaniline were purchased from Tokyo Kasei Industrial Co. $\mathrm{Pd}(\mathrm{OAc})_{2}$ was purchased from Wako Chem. 2-Holotropones were prepared according to the literature method of Doering. ${ }^{19}$ 6-Chloro-5-azabenz $[b]$ azulene (23) was prepared from 1 according to the literature method of Nozoe. ${ }^{4}$ Emission quantum yields were determined by comparison of a total emission area with that of anthracene ( $\Phi=0.27$, upon excitation at $356 \mathrm{~nm}$ in ethanol).

\section{2-(2-Bromoanilino)tropone (20)}

A mixture of 7 (281 mg, $2.00 \mathrm{mM})$, 2-bromoaniline (413 mg, $2.40 \mathrm{mM}), \mathrm{Pd}_{2}(\mathrm{dba})_{3}(55 \mathrm{mg}, 0.060 \mathrm{mM})$, BINAP (75 mg, $0.12 \mathrm{mM})$, and $\mathrm{Cs}_{2} \mathrm{CO}_{3}(912 \mathrm{mg}, 2.80 \mathrm{mM})$ in $5 \mathrm{~mL}$ of toluene was refluxed on an oil bath for $12 \mathrm{~h}$. The resulted reaction mixture was passed through a Celite pad and washed with toluene. After evaporation of the filtrate, the residue was purified by silica gel column chromatography with AcOEt/Hexane (30/70) to give $444 \mathrm{mg}$ (80\% yield) of 20 as slightly brown needles. Mp $84-85{ }^{\circ} \mathrm{C} .{ }^{1} \mathrm{H}$ $\operatorname{NMR}\left(\mathrm{CDCl}_{3}\right) \delta=6.82(\mathrm{td}, J=8.4,0.8 \mathrm{~Hz}, 1 \mathrm{H}), 6.98(\mathrm{~d}, J=10.4 \mathrm{~Hz}, 1 \mathrm{H}), 7.12(\mathrm{~m}, 2 \mathrm{H}), 7.30-7.35(\mathrm{~m}$, $2 \mathrm{H}), 7.38(\mathrm{t}, J=8.4 \mathrm{~Hz}, 1 \mathrm{H}), 7.46(\mathrm{~d}, J=8.4 \mathrm{~Hz}, 1 \mathrm{H}), 7.70(\mathrm{~d}, J=10.8 \mathrm{~Hz}, 1 \mathrm{H}), 8.75(\mathrm{brs}, 1 \mathrm{H}) \mathrm{ppm} ;{ }^{13} \mathrm{C}$ 
NMR $\left(\mathrm{CDCl}_{3}\right) \delta=110.8,120.0,125.2,125.4,127.2,128.3,131.4,133.9,135.7,137.0,137.5,152.7$, $177.2 \mathrm{ppm}$; IR (KBr) $v_{\max }=3427 \mathrm{brm}, 3236 \mathrm{~m}, 1547 \mathrm{vs} \mathrm{cm}^{-1}$; UV-vis $(\mathrm{EtOH}) \lambda_{\max }=236(\log \varepsilon=4.25), 341$ (3.99), 400 (4.10) nm; MS (70 eV) m/z (rel int) = $277\left(\mathrm{M}^{+}, 12\right), 275\left(\mathrm{M}^{+}, 11\right), 276$ (19), 197 (38), 196 (100), 168 (17), 167 (53), 98 (15), 77 (15). Anal. Calcd for $\mathrm{C}_{13} \mathrm{H}_{10} \mathrm{BrNO}$ : C, 56.55; H, 3.65; N, 5.07\%. Found: C, 56.76; H, 3.77; N, 5.15\%.

\section{5,6-Dihydrocyclohepta[b]indol-6-one (1)}

A mixture of 20 (215 mg, $0.779 \mathrm{mM}), \mathrm{XPhos}$ (74 mg, $0.16 \mathrm{mM}), \mathrm{Pd}(\mathrm{OAc})_{2}(18 \mathrm{mg}, 0.080 \mathrm{mM}), \mathrm{NaOAc}$ (128 mg, $1.56 \mathrm{mM})$, and $\mathrm{AcOH}(47 \mu \mathrm{L}, 0.78 \mathrm{mM})$ in $5 \mathrm{~mL}$ of DMF was refluxed on an oil bath for $27 \mathrm{~h}$. The resulted reaction mixture was passed through a Celite pad and washed with $\mathrm{CH}_{2} \mathrm{Cl}_{2}$. After evaporation of the filtrate, the residue was purified by silica gel column chromatography with AcOEt/Hexane (40/60) to give $137 \mathrm{mg}$ (90\% yield) of 1 as yellow prisms. Mp 255-256 ${ }^{\circ} \mathrm{C}$ [lit. 249.5-250.5, $\left.{ }^{1} 250-252,{ }^{2} 245-246{ }^{\circ} \mathrm{C}^{3 \mathrm{a}}\right] .{ }^{1} \mathrm{H} \mathrm{NMR}\left(\mathrm{CDCl}_{3}\right) \delta=7.10(\mathrm{ddd}, J=10.8,8.8,1.0 \mathrm{~Hz}, \mathrm{H}-9), 7.39$ (tt, $J=8.0 .1 .2 \mathrm{~Hz}, \mathrm{H}-2), 7.42(\mathrm{dt}, J=12.3,1.0 \mathrm{~Hz}, \mathrm{H}-7), 7.55$ (ddd, $J=12.3,8.8,1.0 \mathrm{~Hz}, \mathrm{H}-8), 7.58$ (tt, $J$ $=8.0,1.2 \mathrm{~Hz}, \mathrm{H}-3), 7.72(\mathrm{dm}, J=8.0 \mathrm{~Hz}, \mathrm{H}-4), 8.15(\mathrm{dm}, J=8.0 \mathrm{~Hz}, \mathrm{H}-1), 8.20(\mathrm{dm}, J=10.8 \mathrm{~Hz}, \mathrm{H}-10)$, 10.91 (brs, N-H) ppm; ${ }^{1} \mathrm{H}$ NMR $\left(\mathrm{CF}_{3} \mathrm{CO}_{2} \mathrm{D}\right) \delta=7.69$ (m, H-2), $7.90-7.95$ (m, H-3,4), 8.19 (t, J=10.0 Hz, H-9), 8.25 (d, $J=10.0 \mathrm{~Hz}, \mathrm{H}-7), 8.42$ (t, $J=8.4 \mathrm{~Hz}, \mathrm{H}-8), 8.48$ (d, $J=8.4 \mathrm{~Hz}, \mathrm{H}-1), 9.35$ (d, $J=10.0 \mathrm{~Hz}$, $\mathrm{H}-10) \mathrm{ppm} ;{ }^{13} \mathrm{C} \mathrm{NMR}\left(\mathrm{CF}_{3} \mathrm{CO}_{2} \mathrm{D}\right) \delta=115.3,123.4,126.6,127.1,128.1,134.1,135.7,138.2,139.9,141.8$, 142.5, 144.8, $183.1 \mathrm{ppm} ;{ }^{1} \mathrm{H} \mathrm{NMR}\left(\mathrm{NaOD} / \mathrm{D}_{2} \mathrm{O} / \mathrm{DMSO}-d_{6}\right) \delta=6.95$ (t, $\left.J=9.4 \mathrm{~Hz}, \mathrm{H}-9\right), 7.18(\mathrm{~d}, J=11.9$ Hz, H-7), 7.27 (t, $J=8.2 \mathrm{~Hz}, \mathrm{H}-2), 7.46$ (t, $J=8.2 \mathrm{~Hz}, \mathrm{H}-3), 7.52$ (dd, $J=11.9,9.4 \mathrm{~Hz}, \mathrm{H}-8), 7.83$ (d, $J=$ $8.2 \mathrm{~Hz}, \mathrm{H}-4), 8.21$ (d, $J=8.2 \mathrm{~Hz}, \mathrm{H}-1), 8.43$ (d, $J=9.4 \mathrm{~Hz}, \mathrm{H}-10) \mathrm{ppm} ;{ }^{13} \mathrm{C}$ NMR $\left(\mathrm{NaOD} / \mathrm{D}_{2} \mathrm{O} / \mathrm{DMSO}-d_{6}\right)$ $\delta=119.4,120.7,121.3,121.9,127.4,128.5,129.6,130.6,132.4,137.8,152.3,155.8,182.2$ ppm;

\section{6-(1H-Pyrazol-1-yl)-5-azabenz[b]azulene (13)}

A mixture of 23 (45 mg, $0.21 \mathrm{mM})$, pyrazole (29 mg, $0.42 \mathrm{mM}), \operatorname{Pd}_{2}(\mathrm{dba})_{3}(9 \mathrm{mg}, 7 \mu \mathrm{M}), \mathrm{BINAP}(6 \mathrm{mg}$, $14 \mu \mathrm{M})$, and $\mathrm{Cs}_{2} \mathrm{CO}_{3}(137 \mathrm{mg}, 0.420 \mathrm{mM})$ in $5 \mathrm{~mL}$ of toluene was refluxed on an oil bath for $9 \mathrm{~h}$. The resulted reaction mixture was passed through a Celite pad and washed with toluene. After evaporation of the filtrate, the residue was purified by silica gel column chromatography with $\mathrm{AcOEt} / \mathrm{CHCl}_{3}(30 / 70)$ to give $40 \mathrm{mg}$ (77\% yield) of $\mathbf{1 3}$ as violet needles. Mp 135-136 ${ }^{\circ} \mathrm{C} .{ }^{1} \mathrm{H}$ NMR $\left(\mathrm{CDCl}_{3}\right) \delta=6.64(\mathrm{dd}, J=2.7$, $1.3 \mathrm{~Hz}$, pyrazolyl-H), 7.54 (ddd, $J=8.1,7.7,1.0 \mathrm{~Hz}, \mathrm{H}-2), 7.69$ (ddd, $J=10.3,8.9,0.5 \mathrm{~Hz}, \mathrm{H}-9$ ), 7.80 (ddd, $J=8.1,7.7,1.0 \mathrm{~Hz}, \mathrm{H}-3), 7.89$ (dd, $J=1.3,0.5 \mathrm{~Hz}$, pyrazolyl-H), 7.94 (ddd, $J=10.6,10.3,1.0 \mathrm{~Hz}$, H-8), 8.13 (dt, $J=8.1,1.0 \mathrm{~Hz}, \mathrm{H}-4), 8.38$ (dt, $J=8.1,1.0 \mathrm{~Hz}, \mathrm{H}-1), 8.82$ (dd, $J=10.6,1.1 \mathrm{~Hz}, \mathrm{H}-7), 8.88$ (ddd, $J=8.9,1.1,0.5 \mathrm{~Hz}, \mathrm{H}-10), 9.65$ (dd, $J=2.7,0.5 \mathrm{~Hz}$, pyrazolyl-H), ppm; ${ }^{13} \mathrm{C} \mathrm{NMR}\left(\mathrm{CDCl}_{3}\right) \delta=$ 107.8 (pyrazole C-4), 120.8 (C-4), 120.9 (C-1), 122.9 (C-2), 125.9 (C-7), 127.5 (C-9), 127.8 (C-10b), 
131.0 (C-3), 131.2 (C-10), 135.0 (C-8), 135.5 (pyrazole C-5), 142.1 (pyrazole C-3), 142.6 (C-6), 143.8 (C-10a), 152.1 (C-5a), 156.3 (C-4a) ppm; IR (KBr) $v_{\max }=1454 \mathrm{~s}, 1382 \mathrm{~s}, 1334 \mathrm{~s}, 1203 \mathrm{~s}, 1041 \mathrm{~s}, 654 \mathrm{~s}, 755 \mathrm{~s}$, $730 \mathrm{~s} \mathrm{~cm}^{-1}$; UV-vis $(\mathrm{EtOH}) \lambda_{\max }=271(\log \varepsilon=4.29), 311(4.48), 350$ (4.12), 383 (3.92), 510 (3.04) nm; MS (70 eV) m/z (rel int) =246 (M+1, 21), $245\left(\mathrm{M}^{+}, 100\right), 244$ (27), 218 (83), 217 (30), 192 (22), 190 (15), 177 (14), 151 (12). HRMS m/z Calcd for $\mathrm{C}_{16} \mathrm{H}_{11} \mathrm{~N}_{3}\left(\mathrm{M}^{+}\right)$245.0953, found: 245.0915. Anal. Calcd for $\mathrm{C}_{16} \mathrm{H}_{11} \mathrm{~N}_{3}$ : C, 78.35; H, 4.52; N, 17.13\%. Found: C, 78.26; H, 4.79; N, 16.97\%.

\section{6-(1H-1,2,3-Triazol-1-yl)-5-azabenz[b]azulene (14)}

A mixture of 23 (45 mg, $0.21 \mathrm{mM}), 1,2,3$-triazole $(29 \mathrm{mg}, 0.42 \mathrm{mM}), \mathrm{Pd}_{2}(\mathrm{dba})_{3}(19 \mathrm{mg}, 0.021 \mathrm{mM})$, BINAP (26 mg, $0.042 \mathrm{mM}$ ), and $\mathrm{Cs}_{2} \mathrm{CO}_{3}(137 \mathrm{mg}, 0.420 \mathrm{mM})$ in $5 \mathrm{~mL}$ of toluene was heated at $90{ }^{\circ} \mathrm{C}$ on an oil bath for $20 \mathrm{~h}$. The resulted reaction mixture was passed through a Celite pad and washed with toluene. After evaporation of the filtrate, the residue was purified by silica gel column chromatography with $\mathrm{AcOEt} / \mathrm{CH}_{2} \mathrm{Cl}_{2}$ (40/60) to give $37 \mathrm{mg}$ (72\% yield) of 14 as violet needles. Mp $189-191{ }^{\circ} \mathrm{C}$. ${ }^{1} \mathrm{H}$ NMR $\left(\mathrm{CDCl}_{3}\right) \delta=7.60(\mathrm{td}, J=8.0,0.8 \mathrm{~Hz}, \mathrm{H}-2), 7.86(\mathrm{~m}, \mathrm{H}-3,9), 7.98(\mathrm{~d}, J=1.2 \mathrm{~Hz}$, triazolyl-H), $7.99(\mathrm{td}, J=$ $10.2,1.0 \mathrm{~Hz}, \mathrm{H}-8), 8.13$ (dt, $J=8.0,0.8 \mathrm{~Hz}, \mathrm{H}-4), 8.43$ (dt, $J=8.0,0.9 \mathrm{~Hz}, \mathrm{H}-1), 8.79$ (d, $J=10.2 \mathrm{~Hz}$, $\mathrm{H}-7), 8.94$ (dd, $J=8.6,1.0 \mathrm{~Hz}, \mathrm{H}-10), 9.51$ (d, $J=1.2 \mathrm{~Hz}$, triazolyl-H), ppm; ${ }^{13} \mathrm{C} \mathrm{NMR}\left(\mathrm{CDCl}_{3}\right) \delta=$ 120.8(C-4), 121.2 (C-1), 123.1 (C-2), 127.4 (C-7), 128.1 (C-9), 129.0 (C-10b), 130.0 (C-3), 130.8 (C-10), 132.2 (C-8), 134.4 (triazole C-4), 134.9 (triazole C-5), 139.3 (C-6), 145.1 (C-10a), 151.7 (C-5a), 156.9 (C-4a) ppm; IR (KBr) $v_{\max }=3348 \mathrm{~m}, 3168 \mathrm{~m}, 3109 \mathrm{~s}, 3047 \mathrm{~m}, 1616 \mathrm{w}, 1604 \mathrm{~m}, 1517 \mathrm{w}, 1475 \mathrm{w}, 1458 \mathrm{~s}$, $1437 \mathrm{w}, 1394 \mathrm{~s}, 1357 \mathrm{~m}, 1330 \mathrm{~m}, 1321 \mathrm{w}, 1236 \mathrm{~s}, 1070 \mathrm{~s}, 1016 \mathrm{~s}, 789 \mathrm{~m}, 758 \mathrm{~s}, 727 \mathrm{~s} \mathrm{~cm}^{-1}$; UV-vis (EtOH) $\lambda_{\max }$ $=245(\log \varepsilon=4.18), 258 \mathrm{sh}(4.17), 274$ (4.12), 300sh (4.38), 317 (4.48), 368 (3.55), 385 (3.70), 401sh (3.39), 514 (2.78) nm; MS (70 eV) m/z (rel int) = $246\left(\mathrm{M}^{+}, 3\right), 218$ (100), 217 (27), 190 (18), 177 (12), 167 (9), 151 (9), 150 (6), 108 (8), 106 (7), 77 (7), 57 (8). HRMS m/z Calcd for $\mathrm{C}_{16} \mathrm{H}_{11} \mathrm{~N}_{4}\left(\mathrm{M}^{+}\right)$246.0911, found: 246.0904.

\section{Determination of acidity and basicity for 1 and 13}

The acidity of $\mathbf{1}$ and basicity of $\mathbf{1 3}$ were determined from titration curves based on $\mathrm{pH}$-dependent absorption spectra in $50 \%$ aqueous ethanol solutions by a curve fitting method using KaleidaGraph program. The absorption peak at $455 \mathrm{~nm}$ for acidity of $\mathbf{1}$ and the absorption peak at $383 \mathrm{~nm}$ for basicity of 13 were used. Buffer solutions used for measurements of basicity of $\mathbf{1 3}$ are as follows; $\mathrm{AcOH} / \mathrm{AcONa}$ at a range of $\mathrm{pH} 4.35 \sim 7.40$ and $\mathrm{KH}_{2} \mathrm{PO}_{4} / \mathrm{Na}_{2} \mathrm{HPO}_{4}$ at a range of $\mathrm{pH}$ 6.97 8.92. Instead buffer solutions, $\mathrm{NaOH}$ solutions were used a range of $\mathrm{pH} 10.50 \sim 14.00$ for measurements of acidity of $\mathbf{1}$. The basicity of 1 was determined from titration curves based on Hammet acitity function $\left(H_{0}\right)$-dependent absorption spectra. The absorption peak at $402 \mathrm{~nm}$ was used and solutions used are as follows; $\mathrm{H}_{3} \mathrm{PO}_{4}$ solutions at a range of 
$H_{0}-0.37 \sim 1.45$ and $\mathrm{H}_{2} \mathrm{SO}_{4}$ solutions at a range of $H_{0}-2.06 \sim 0.02$.

\section{ACKNOWLEDGEMENTS}

We deeply thank emeritus Prof. Kunihide Fujimori at Shinshu University for giving us an authentic sample of 1. We also thank Mr Hiroki Okamoto and Ms Yuko Yamaga for their technical assistance to prepare compound 14.

\section{REFERENCES AND NOTES}

1. The compound has also been called as indolo[2,3-b]tropone.

2. J. De Jong and J. H. Boyer, J. Org Chem., 1972, 37, 3571.

3. S. Yamada, M. Ishikawa, and C. Kaneko, Tetrahedron Lett., 1972, 13, 977; Chem. Pharm. Bull., $1975, \mathbf{2 3}, 2818$.

4. a) T. Nozoe, J.-K. Sin, K. Yamane, and K. Fujimori, Bull. Chem. Soc. Jpn., 1975, 48, 314; b) K. Yamane and K. Fujimori, Bull. Chem. Soc. Jpn., 1976, 49, 1101.

5. Nozoe et al. also reported that $\mathbf{1}$ was obtained as a minor product in rearrangement of 2-(2-phenylhydrzino)tropone; T. Nozoe, K. Takase, H. Saito, H. Yamamoto, and K. Imafuku, Chem. Lett., 1986, 1577; T. Nozoe, K. Takase, M. Yasunami, M. Ando, H. Saito, K. Imafuku, B.-Z. Yin, M. Honda, Y. Goto, T. Hanaya, Y. Hara, and H. Yamamoto, Bull. Chem. Soc. Jpn., 1989, 62, 128.

6. For isolation and total synthesis of caulersin, see; a) J.-Y. Su, Y. Zhu, L.-M. Zeng, and X.-H. Xu, J. Nat. Prod., 1997, 60, 1043; b) P. M. Fresneda, P. Molina, and M. A. Saez, Synlett, 1999, 1651; c) N. Wahlström, B. Stensland, and J. Bergman, Tetrahedron, 2004, 60, 2147; d) Y. Miki, Y. Aoki, H. Miyatake, T. Minematsu, and H. Hibino, Tetrahedron Lett., 2006, 47, 5215.

7. B. Joseph, D. Alagille, J.-Y. Mérour, and S. Léonce, Chem. Pharm. Bull., 2000, 48, 1872.

8. a) Y. Sugihara, K. Murafuji, N. Abe, T. Takeda, and A. Kakei, New J. Chem., 1998, 22, 1031; b) H. Fujii, N. Abe, N. Umeda, and A. Kahei, Heterocycles, 2002, 58, 283; c) N. Abe, Y. Harada, Y. Imachi, H. Fujii, A. Kahei, and M. Shiro, Heterocycles, 2007, 72, 459; d) K. Koizumi, C. Miyake, T. Ariyoshi, K. Umeda, N. Yamauchi, S. Tagashira, Y. Murakami, H. Fujii, and N. Abe, Heterocycles, 2007, 73, 325; e) M. Oda, K. Ogura, N. C. Thanh, S. Kishi, S. Kuroda, K. Fujimori, T. Noda, and N. Abe, Tetrahedron Lett., 2007, 48, 4471; f) T. Ariyoshi, T. Noda, S. Watarai, S. Tagashira, Y. Murakami, H. Fujii, and N. Abe, Heterocycles, 2009, 77, 565; g) M. Oda, D. Miyawaki, N. Matsumoto, and S. Kuroda, Heterocycles, 2011, 83, 547; h) M. Oda, A. Sugiyama, R. Takeuchi, Y. Fujiwara, R. Miyatake, T. Abe, and S. Kuroda, Eur. J. Org. Chem., 2012, 2231.

9. A part of this study, development of the novel synthetic procedure of $\mathbf{1}$, has been briefly reported; $\mathbf{J}$. Jin, K. Ito, F. Takahashi, and M. Oda, Chem. Lett., 2010, 39, 861. 
10. a) S. Iseda, Bull. Chem. Soc. Jpn., 1955, 28, 617; b) S. Iseda, Bull. Chem. Soc. Jpn., 1957, 30, 694; c) T. Mukai, Bull. Chem. Soc. Jpn., 1959, 32, 272; d) T. Nozoe, H. Okai, and T. Someya, Bull. Chem. Soc.Jpn., 1978, 51, 2185; e) R. M. Claramunt, D. Sanz, M. Pérez-Torralba, E. Pinilla, M. R. Torres, and J. Elguero, Eur. J. Org. Chem., 2004, 4452; f) M. Dochnahl, K. Löhnwitz, J.-W. Pissarek, M. Biyikal, S. R. Schulz, S. Schön, N. Meyer, P. W. Roesky, and S. Blechert, Chem. Eur. J., 2007, 13, 6654.

11. F. A. Hicks and M. Brookhart, Org. Lett., 2000, 2, 219.

12. G. Bartoli and P. E. Todesco, Acc. Chem. Res., 1977, 10, 125.

13. XPhos is a trivial name of 2-dicyclohexylphosphino- 2',4',6'-triisopropylbiphenyl; X. Huang, K. W. Anderson, D. Zim, L. Jiang, A. Klapars, and S. L. Buchwald, J. Am. Chem. Soc., 2003, 125, 6653.

14. F. G. Bordwell, G. E. Drucker, and H. E. Froed, J. Org. Chem., 1981, 46, 632.

15. S. Seto, T. Hiratsuka, and H. Toda, Yakugaku Zashi, 1969, 89, 1673.

16. H. Hosoya and S. Nagakura, Bull. Chem. Soc. Jpn., 1966, 39, 1414.

17. Upon excitation at $403 \mathrm{~nm}$ in $\mathrm{EtOH}, 1$ emits light with a maximum at $439 \mathrm{~nm}$. The quantum yield was obtained in a molar concentration of 1 less than $10^{-5} \mathrm{~mol} / \mathrm{L}$.

18. Emission quauntum yields for $\mathbf{1 3}$ and 14 are $7.4 \times 10^{-4}$ and $3.8 \times 10^{-4}$, respectively. Quantum yields were obtained in molar concentrations of these substrates less than $10^{-4} \mathrm{~mol} / \mathrm{L}$.

19. W. v. E. Doering and L. H. Knox, J. Am. Chem. Soc., 1952, 74, 5683. 